\title{
Biomphalaria molluscs (Gastropoda: Planorbidae) in Rio Grande do Sul, Brazil
}

\author{
Michele Soares Pepe ${ }^{1 /+}$, Roberta Lima Caldeira², Omar dos Santos Carvalho², Gertrud Muller', \\ Liana Konovaloff Jannotti-Passos ${ }^{2,3}$, Alice Pozza Rodrigues' ${ }^{1}$, Hugo Leonardo Amaral', \\ Maria Elisabeth Aires Berne ${ }^{1}$
}

'Departamento de Microbiologia e Parasitologia, Instituto de Biologia, Universidade Federal de Pelotas, CP 354, 96010-900 Pelotas, RS, Brasil ${ }^{2}$ Laboratório de Helmintologia e Malacologia Médica ${ }^{3}$ Moluscário Lobato Paraense, Instituto de Pesquisas René Rachou-Fiocruz, Belo Horizonte, MG, Brasil

The present study was aimed at characterising Biomphalaria species using both morphological and molecular (PCR-RFLP) approaches. The specimens were collected in 15 localities in 12 municipalities of the southern region of the state of Rio Grande do Sul, Brazil. The following species were found and identified: Biomphalaria tenagophila guaibensis, Biomphalaria oligoza and Biomphalaria peregrina. Specimens of the latter species were experimentally challenged with the LE Schistosoma mansoni strain, which showed to be refractory to infection.

Key words: Biomphalaria sp - Southern Brazil - experimental infection

Freshwatersnails belonging to the genus Biomphalaria are intermediate hosts of Schistosoma mansoni, the etiological agent of schistosomiasis. Among the Biomphalaria species that occur in Brazil, three are regarded as intermediate hosts of $S$. mansoni, namely, Biomphalaria glabrata, Biomphalaria tenagophila and Biomphalaria straminea. Investigations on experimental infection using Biomphalaria peregrina and Biomphalaria amazonica have shown that they are potential hosts for the trematode (Corrêa \& Paraense 1971, Paraense \& Corrêa 1973).

In Rio Grande do Sul (RS), Brazil, there have been reports on the occurrence of $B$. tenagophila (Paraense \& Deslandes 1959), B. straminea (Cunha Neto 1972), Biomphalaria oligoza (Paraense 1974), B. peregrina (Paraense 1966), Biomphalaria tenagophila guaibensis (Paraense 1984) and B. glabrata (Carvalho et al. 1998). The presence of $S$. mansoni in the state has been associated with the occurrence of B. glabrata in water collections surrounding Rio dos Sinos, in the municipality of Esteio (Graeff-Teixeira et al. 1999).

Considering the fact that little is known on freshwater snail diversity in the Southern Region of Brazil, the aim of the present study was to identify the Biomphalaria species in this region and assess their susceptibility to $S$. mansoni infection, either as intermediate hosts and/or as potential hosts. Molluscs were collected in 15 localities of 12 municipalities of RS during 2005. The collection areas included: Arroio Grande, Bagé, Camaquã, Can-

+ Corresponding author: micpepe2@yahoo.com.br

Received 5 August 2008

Accepted 3 March 2009 guçu, Capão do Leão, Dom Pedrito, Jaguarão, Pelotas, Rio Grande, Rosário do Sul, Santa Vitória do Palmar and São Gabriel, between the $30-34^{\circ}$ parallels and the 51-55 ${ }^{\circ}$ meridians. The molluscs collected were sent to our laboratory to obtain their F1 progeny. Morphological and molecular identification of Biomphalaria was undertaken according to Paraense $(1975,1981,1984)$ and Vidigal et al. (2000), respectively.

Specimens of $B$. peregrina (São João Batista do Glória/MG), B. oligoza (Eldorado do Sul/RS), B. t. guaibensis (Esteio/RS) and Biomphalaria occidentalis [Belo Horizonte, Minas Gerais (MG)], previously identified by both morphological and molecular means, were included for comparison. The snails were identified as $B$. oligoza, $B$. peregrina and B. $t$. guaibensis both through their morphology and the use of molecular techniques (Fig. 1). Since the genetic profiles of B. t. guaibensis and $B$. occidentalis appeared to be similar when digested with the restriction enzyme $D d e I$, the amplified fragments that had been previously identified as B. t. guaibensis were then digested with AluI since it allows differentiation between these species (Fig. 2). Table shows the field-collected snails, B. oligoza, B. peregrina and B. $t$. guaibensis in RS.

Groups of $50 \mathrm{~F} 1$ - snails (4-6 mm) from two B. peregrina populations collected in the municipalities of Rio Grande and Dom Pedrito (Estrada do Meio) were individually challenged with 100 miracidia/mollusc of the LE $S$. mansoni strain. As an infection control, we included 50 B. glabrata specimens from Barreiro de Cima, Belo Horizonte (MG), infected with 20 miracidia /mollusc of the same strain, which had been kept in the Moluscário Lobato Paraense at Instituto de Pesquisas René-Rachou-Fiocruz (MG). The susceptibility levels in these populations were assessed by light exposure and squeezing (Souza \& Lima 1997). All field-collected molluscs were determined to be $S$. mansoni-negative. 


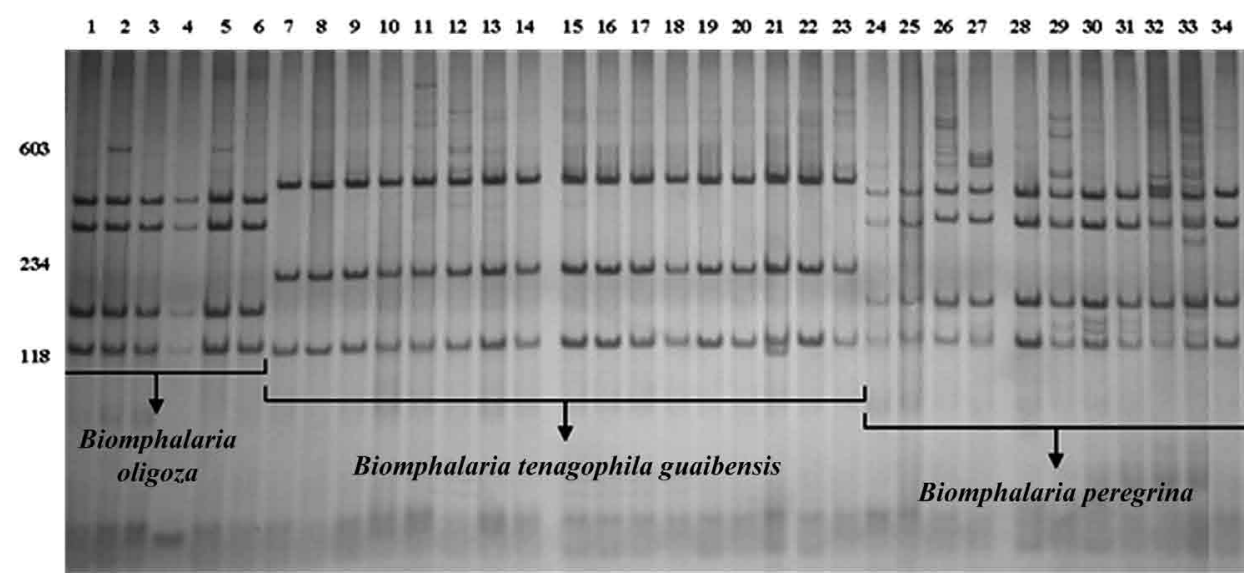

Fig. 1: 6\% silver stained polyacrylamide gel showing the restriction profiles after digestion of the ITS region of ribosomal RNA with $D d e$ I. Lane 1: B. oligoza [Eldorado do Sul, Rio Grande do Sul (RS)]; 2-3: Canguçu; 4-5: Capão do Leão (Fazenda Bela Vista); 6: São Gabriel; 7: $B$. tenagophila guaibensis [Esteio (RS)]; 8-9: Pelotas (Barragem SANEP); 10-11: Arroio Grande (Barragem Chasqueiro); 12-13: Santa Vitória do Palmar (Granja Figueira); 14-15: Dom Pedrito (Passinho do Amor); 16-17: Camaquã (Pacheca); 18-19: Santa Vitória do Palmar (Estância Ipiranga); 20-21: Jaguarão (Granja Bretanha); 22-23: Alegrete; 24: B. peregrina [São João Batista da Glória (MG)]; 25-26: Bagé; 27-28: Rio Grande; 29-30: Dom Pedrito (Chácara do Cedro); 31-32: Dom Pedrito (Estrada do Meio); 33-34: Rosário do Sul (Santa Ambrosina). Molecular size are on the left (X 174).

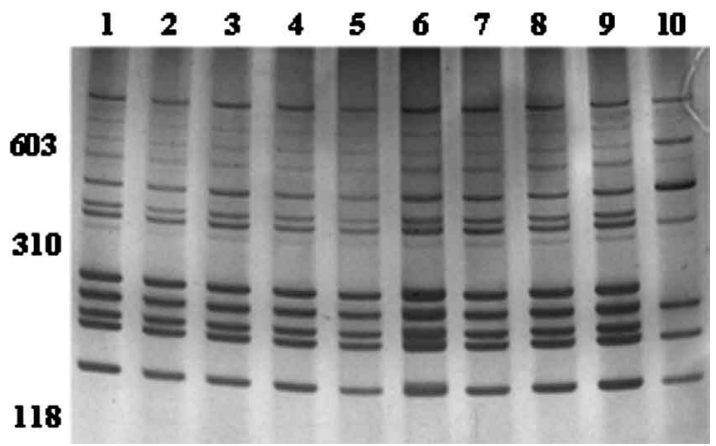

Fig. 2: $6 \%$ silver stained polyacrylamide gel showing the restriction profiles after digestion of the ITS region of ribosomal RNA with AluI. Lanes 1-2: Biomphalaria tenagophila guaibensis (Esteio, Rio Grande do Sul); 3: B. t. guaibensis (Pelotas); 4: B. t. guaibensis (Arroio Grande); 5: B. t. guaibensis (Santa Vitória do Palmar/Granja Figueira); 6: B. t. guaibensis (Dom Pedrito/Passinho do Amor); 7: B. t. guaibensis (Camaquã); 8: B. t. guaibensis (Santa Vitória do Palmar/ Estância Ipiranga); 9: B. t. guaibensis (Jaguarão); 10: Biomphalaria occidentalis (Belo Horizonte, Minas Gerais). Molecular size are on the left (X 174).

Light exposure examinations of F1 progeny from two $B$. peregrina populations that had been challenged with $S$. mansoni miracidia showed no evidence of either cercariae or sporocysts. The mortality rate of the snails ranged from $0-16 \%$.

The present investigation constitutes the first report on the occurrence of B.t. guaibensis in the municipalities of Camaquã, Dom Pedrito and Santa Vitória do Palmar. Although a survey by Teles et al. (1991) showed no evidence of such species in RS, Paraense (1984) had reported its occurrence in Arroio Grande, Jaguarão and Pelotas (RS).
B. oligoza is also being reported for the first time in Canguçu, Capão do Leão and São Gabriel and was previously reported by Paraense (1974), Fróes and Lima (1975) and Pereira et al. (2000) in the municipalities of Filipson, Gravataí, Guaíba, Lagoa Vermelha, Mariana Pimentel, Morro Reuter, Nova Petrópolis, Porto Alegre, Santo Antonio, Seival, Tramandaí, Triunfo, Tupanciretã and Viamão. In Bagé, Dom Pedrito, Rio Grande and Rosário do Sul, previous reports have described the presence of B. peregrina (Paraense 1966, Fróes \& Lima 1975). In addition to these municipalities, the authors also reported the occurrence of B. peregrina in Camaquã, Jaguarão, Pelotas and São Gabriel. The results of our study, however, showed no occurrence of B. peregrina, which may be due to differences in the collection areas.

Early studies of shell morphology and the internal anatomy of planorbids were conducted to identify suitable traits for accurate and reliable species identification (Paraense 1972, 1975). In some B. t. guaibensis specimens from different populations than those analysed in our study, a dark pigmentation was observed on the renal tube, which had not been reported by Paraense (1984). Among the planorbid species described in Brazil, the only species known to have a pigmented renal tube is B. glabrata, the main $S$. mansoni transmitter species in Brazil (Paraense 1975). According to Paraense (1972), the specific trait found in B. glabrata and the main feature used to differentiate it from $B$. tenagophila is the pigmented crest that extends along the renal tube. This pigmentation found in B. tenagophila guaibensis might be due to either intraspecific variation or contact with staining substances present in the water collections (Paraense 1972).

Specific morphological characteristics described by Paraense $(1966,1974)$ were observed in the $B$. peregri$n a$ and $B$. oligoza populations analysed in our present 


\section{TABLE}

Biomphalaria species identified through morphological and molecular techniques collected in municipalities in the state of Rio Grande do Sul

\begin{tabular}{lcc}
\hline Municipalities & Origin of snails & species \\
\hline Arroio Grande & Barragem Chasqueiro & Biomphalaria tenagophila guaibensis \\
Bagé & Bagé & Biomphalaria peregrina \\
Camaquã & Pacheca & B. t. guaibensis \\
Canguçu & Cabanha Cafundó & Biomphalaria oligoza \\
Capão do Leão & Fazenda Bela Vista & B. oligoza \\
Dom Pedrito & Passinho do Amor & B.t. guaibensis \\
Dom Pedrito & Chácara do Cedro & B. peregrina \\
Dom Pedrito & Estrada do Meio & B. peregrina \\
Jaguarão & Granja Bretanha & B. t. guaibensis \\
Pelotas & Barragem SANEP & B.t. guaibensis \\
Rio Grande & Rio Grande & B. peregrina \\
Rosário do Sul & Estância Santa Ambrosina & B. peregrina \\
Santa Vitória do Palmar & Estância Ipiranga & B. t. guaibensis \\
Santa Vitória do Palmar & Granja Figueira & B.t. guaibensis \\
São Gabriel & São Gabriel & B. oligoza
\end{tabular}

study. Such identification was corroborated by molecular analysis, which has been shown to be a useful tool for differentiating two morphologically similar species (Caldeira et al. 1998, Spatz et al. 2000, Vidigal et al. 2000). As both diagnostic methods are compatible, morphological traits should be used for routine identification, while molecular approaches should be employed in inconclusive cases.

The populations of $B$. peregrina used for the susceptibility tests (from Dom Pedrito and Rio Grande) showed no evidence of either $S$. mansoni cercariae or sporocysts. A similar result was obtained by Souza et al. (1988), who reported no $B$. peregrina infection in a mollusc population from Santa Rita do Sapucaí (MG), even when challenged with three different $S$. mansoni strains [From Belo Horizonte (MG), São José dos Campos (state of São Paulo) and state of Alagoas]. In addition, Paraense and Corrêa (1973) have reported similar resistance in a $B$. peregrina population collected in Pouso Alegre (MG), which is adjacent to the city of Santa Rita do Sapucaí (MG). However, B. peregrina populations from Lapa (state of Paraná) and from the Equator were found to be susceptible to $S$. mansoni infection, and they may be regarded as potential hosts for the trematode in these regions (Paraense \& Corrêa 1973).

In the present study, by analysing snail populations susceptible to $S$. mansoni infection, we found that both B. peregrina populations, from Rio Grande and Dom Pedrito - Estrada do Meio, showed mortality rates ranging from $0-4.17 \%$. These rates differ from those observed by Souza et al. (1988), who reported 0-20\% mortality rates in the six populations they analysed, three of which showed a $12 \%$ mortality rate. These authors have also observed that the number of $S$. mansoni miracidia used for infection as well as the origins of the strains did not seem to affect the mortality indices.
The rates of infection and of mortality in the control group, B. glabrata from Barreiro de Cima, were 52\% and $16 \%$, respectively.

The susceptibility level of these different Biomphalaria species to infection by the same strain of S. mansoni varies greatly (Paraense \& Corrêa 1973, 1978). Besides the difference in susceptibility observed between Biomphalaria species compatible with the parasite, some strain or geographical isolates of the same species of Biomphalaria also presented great variation in susceptibility to the parasite.

Given that $S$. mansoni is highly specific to its intermediate host, a survey of the areas where Biomphalaria occurs is useful, as it provides invaluable information to help design schistosomiasis control measures.

\section{REFERENCES}

Caldeira RL, Vidigal THDA, Paulinelli ST, Simpson AJG, Carvalho OS 1998. Molecular identification of similar species of the genus Biomphalaria (Mollusca: Planorbidae) determined by a polymerase chain reaction-restriction fragment length polymorphism. Mem Inst Oswaldo Cruz 93: 219-225.

Carvalho OS, Nunes IM, Caldeira RL 1998. First report of Biomphalaria glabrata in the state of Rio Grande do Sul, Brazil. Mem Inst Oswaldo Cruz 93: 39-40.

Corrêa LR, Paraense WL 1971. Susceptibility of Biomphalaria amazonica to infection with two strains of Schistosoma mansoni. Rev Inst Med Trop Sao Paulo 13: 387-390.

Cunha Neto AG 1972. Biomphalaria straminea em Porto Alegre, Rio Grande do Sul, Brasil. Atas Sociedade Biologia 15: 157.

Fróes OM, Lima DF 1975. Contribuição ao estudo da biogeografia, sistemática e ecologia dos Planorbídeos (Gastropoda: Planorbidae) do Rio Grande do Sul. Iheringia Zool 47: 67-72.

Graeff-Teixeira C, Anjos CB, Oliveira VC, Velloso CFP, Fonseca MBS, Valar C, Moraes C, Garrido CT, Amaral RS 1999. Identification of a transmission focus of Schistosoma mansoni in 
the Southernmost Brazilian State, Rio Grande do Sul. Mem Inst Oswaldo Cruz 94: 9-10.

Paraense WL 1966. The synonymy and distribution of Biomphalaria peregrina in the Neotropical Region. Rev Bras Biol 26: 269-296.

Paraense WL 1972. Fauna planorbídica do Brasil. In CS Lacaz, RG Paruzzi, W Siqueira-Junior (eds.), Introdução à geografia médica do Brasil, Edgard Blucher \& Editora Universidade de São Paulo, São Paulo, p. 213-239.

Paraense WL 1974. Biomphalaria oligoza n.n. for Tropicorbis philippianus (Dunker) sensu Lucena. Rev Bras Biol 34: 379-386.

Paraense WL 1975. Estado atual da sistemática dos planorbídeos brasileiros. Arq Mus Nac RJ 55: 105-128.

Paraense WL 1981. Biomphalaria occidental is sp.n. from South America (Mollusca: Basommatophora: Pulmonata). Mem Inst Oswaldo Cruz 76: 199-211.

Paraense WL 1984. Biomphalaria tenagophila guaibensis spp.n. from Southern Brazil and Uruguay (Pulmonata: Planorbidae). I. Morphology. Mem Inst Oswaldo Cruz 79: 465-469.

Paraense WL, Corrêa LR 1973. Susceptibility of Biomphalaria peregrina from Brazil and Ecuador to two strains of Schistosoma mansoni. Rev Inst Med Trop Sao Paulo 15: 127-130.

Paraense WL, Corrêa LR 1978. Differential susceptibility of Biomphalaria tenagophila populations to infection with a strain of Schistosoma mansoni. J Parasitol 64: 822-826.
Paraense WL, Deslandes N 1959. The renal ridge as a reliable character for separating Taphius glabratus from Taphius tenagophilus. Am J Trop Med Hyg 8: 456-472.

Pereira D, Mendes ILV, Mansur MCD, Silva MCP 2000. Malacofauna límnica do sistema de irrigação da microbacia arroio Capivara, Triunfo, RS, Brasil. Biociências 8: 137-157.

Souza CP, Lima LC 1997. Moluscos de interesse parasitológico do Brasil, FIOCRUZ/CPqRR, Belo Horizonte, 2nd ed., 79 pp.

Souza CP, Passos LKJ, Carvalho OS 1988. Resistência de Biomphalaria peregrina de Santa Rita do Sapucaí, Minas Gerais, à infecção com três cepas de Schistosoma mansoni. Mem Inst Oswaldo Cruz 83: 447-450.

Spatz L, Vidigal THDA, Silva MCA, Neto ED, Cappa SMG, Carvalho OS 2000. Characterization of Biomphalaria orbignyi, Biomphalaria peregrina and Biomphalaria oligoza by polymerase chain reaction and restriction enzyme digestion of the internal transcribed spacer region of the RNA ribosomal gene. Mem Inst Oswaldo Cruz 95: 807-814.

Teles HMS, Pereira PAC, Richinitti LMA 1991. Distribuição de Biomphalaria (Gastropoda) nos Estados do Rio Grande do Sul e Santa Catarina, Brasil. Rev Saude Publica 25: 350-352.

Vidigal THDA, Caldeira RL, Simpson AJG, Carvalho OS 2000. Further studies on the molecular systematics of Biomphalaria snails from Brazil. Mem Inst Oswaldo Cruz 95: 57-66. 